\title{
The Effect of Endogenous Antibody on Insulin-assay in the Newborn Infants of Diabetic Mothers
}

\author{
T. E. Isles and J.W. FARQUHAR \\ Department of Child Life and Health, University of Edinburgh, and \\ the Simpson Memorial Maternity Pavilion, The Royal Infirmary of Edinburgh, Scotland
}

\begin{abstract}
Extract
The immunoassay of insulin in blood of infants born to diabetic mothers is complicated by the presence of anti-insulin antibodies.

Twelve infants born to diabetic mothers receiving insulin up to the time of delivery (Group 1) and two born to diabetic mothers maintained by dietary restrictions without insulin (Group 2) were studied. Four infants born to normal mothers served as controls (Group 3). The range of values in cord blood of infants of Group 1 was 80-1000 (median 550) (method of Hales and RaNDLE) and 33 to $72.5 \%$ (median 53.8 ) of the radioactivity was bound to plasma proteins. In one infant in Group 1 , maximum amount of the radioactivity $(42.3 \%)$ from labeled insulin $(43 \%)$ was bound to a $\gamma$-globulin $(0 \%$ in Groups 2 and 3$)$. In one infant in Groups 2 and 3 maximum amount of radioactivity was in the $\alpha$-globulin fraction ( 44.1 and $35.3 \%$ respectively).

At 120 minutes after birth, glucose, $0.5 \mathrm{gm} / \mathrm{kg}$ body weight, was infused quickly into the umbilical vein of 6 patients in Group 1 and the two in Group 2. In the former, insulin levels rose significantly, 1- to 4-fold, despite the elevated level at commencement of infusion; in the latter, the insulin levels rose 4-fold in one case and 18-fold in the second. The amount of anti-insulin antibody present in serum of infants in Group 1 did not change significantly during the first 240 minutes after birth; neither was it affected by the administration of glucose and the subsequent appearance of endogenous insulin.
\end{abstract}

\section{Speculation}

Although the infant born to a diabetic mother has elevated levels of insulin and circulating antiinsulin antibodies, his ability to release insulin following a glucose challenge appears unimpaired. This combination of abnormalities suggests an alteration in glucose homeostasis, but fails to explain the hypoglycemia commonly seen in such infants, unless the anti-insulin antibodies do not interfere with the hypoglycemic effects of insulin.

\section{Introduction}

The development of immuno-chemical methods for the assay of insulin following the work of YALOW and BERson [1960] has made readily available suitable microtechniques which are specific for the insulin molecule. The present paper outlines a study to investigate the production of insulin in the newborn infants of diabetic mothers and to confirm and extend the work previously reported by BAIRD and FARQUHAR [1962]. Some of the problems encountered, which were due to interference in the immuno-chemical assay procedures by endogenous maternal antibodies to insulin, are discussed. 


\section{Patients and Methods}

The infants described were born at the Simpson Memorial Maternity Pavilion to fourteen diabetic women of whom twelve had been treated with insulin up to the time of delivery (table I). One other had received insulin over a four-year period but had had none in the eight years prior to this birth, having had dietary treatment and chlorpropamide. Another had been treated with diet alone. The mothers of the four control infants were judged to be normal. These infants were born at full-term and were of normal birth weight. The mothers had no family history of diabetes mellitus, and their previous obstetric records were unremarkable. Each had had an average of twelve urine tests from first reporting for antenatal care up to the actual delivery, and none had glycosuria. Under these circumstances further glucose tolerance testing was not undertaken.

The plasma insulin was studied only in the cord blood of some babies, but in others this was accompanied by an investigation of the plasma insulin response to the injection of glucose. When this was to be done the baby was first given a placental transfusion in order to ensure an adequate blood volume. The method of injecting glucose into and of taking blood samples from the umbilical vein was similar to that previously used (BAIRD and FARQUHAR [1962]) but the tip of the catheter was positioned at less than $7.5 \mathrm{~cm}$ from the anterior abdominal wall in most cases when blood was freely obtained.

Glucose was injected at exactly two hours after birth, and plasma insulin ${ }^{1}$ was determined before and so far as this was possible on seven occasions after the glucose had been given. The dose of glucose was again calculated as $0.5 \mathrm{~g}$ per $\mathrm{kg}$ body weight, and it was given quickly as a $20 \%$ solution. All infants were handled as little as possible and were nursed comfortably at an environmental temperature of approximately $32^{\circ} \mathrm{C}$.

Plasma insulin was measured by immuno-assay techniques. These methods use a specific antiserum for sampling mixtures of insulin and radioactive insulin

1 The term 'insulin' here means immunologicallyreactive insulin under the conditions of the method used.

Table I. Clinical details

\begin{tabular}{|c|c|c|c|c|c|c|}
\hline Case No. & $\begin{array}{l}\text { Age of } \\
\text { mother } \\
\text { (years) }\end{array}$ & $\begin{array}{l}\text { Duration of } \\
\text { mother's } \\
\text { diabetes } \\
\text { (years) }\end{array}$ & $\begin{array}{l}\text { Treatment of } \\
\text { mother }\end{array}$ & Mode of delivery & $\begin{array}{l}\text { Maturity } \\
\text { of baby } \\
\text { (days) }\end{array}$ & $\begin{array}{l}\text { Weight } \\
\text { of baby } \\
\text { (grams) }\end{array}$ \\
\hline \multicolumn{7}{|l|}{ Normals } \\
\hline J.4400 & 29 & 一 & - & vaginal & 277 & 3400 \\
\hline J.4491 & 22 & 一 & - & vaginal & 280 & 3430 \\
\hline J.4658 & 22 & - & - & vaginal & 276 & 3600 \\
\hline J. 4688 & 29 & 一 & 一 & vaginal & 275 & 3690 \\
\hline \multicolumn{7}{|l|}{ Diabetics } \\
\hline 296 & 22 & 9 & diet + insulin & vaginal & 257 & 3690 \\
\hline 297 & 33 & 12 & diet + insulin & caesarean section & 231 & 2810 \\
\hline 298 & 30 & 16 & diet + insulin & caesarean section & 254 & 3570 \\
\hline 299 & 26 & 12 & diet + insulin & caesarean section & 244 & 3200 \\
\hline 300 & 23 & 2 & dict + insulin & caesarean section & 252 & 2880 \\
\hline 302 & 27 & 17 & diet + insulin & caesarean section & 255 & 4110 \\
\hline 303 & 28 & in pregnancy & diet + insulin & caesarean section & 257 & 3230 \\
\hline 307 & 33 & 17 & diet + insulin & vaginal & 258 & 3690 \\
\hline 309 & 24 & in pregnancy & diet & vaginal & 248 & 3840 \\
\hline 310 & 28 & 13 & $\begin{array}{l}\text { diet }+ \text {-insulin } \\
1953-1957 \\
\text { then dict }+- \\
\text { chlorpropamide }\end{array}$ & caesarean section & 233 & 2060 \\
\hline 311 & 23 & 16 & diet + insulin & caesarean section & 245 & 2230 \\
\hline 313 & 19 & 1 & diet + -insulin & caesarean section & 256 & 4680 \\
\hline 314 & 33 & 29 & diet + insulin & vaginal & 247 & 2040 \\
\hline 315 & 31 & 5 & diet + insulin & caesarean section & 247 & 2610 \\
\hline
\end{tabular}


under conditions where the proportion of antibodybound radioactivity is related to the non-radioactive insulin concentration.

The procedures used were based on those of YaLow and BERSON [1960], in which the antibody-bound insulin and the free insulin were separated by paper chromatography using $0.072 \mathrm{M}$ barbitone buffer, $\mathrm{pH}$ 8.6 as solvent, and of HALEs and RANDLE [1963] in which cellulose acetate filters were used to retain the bound insulin. This method is fully described in The Radiochemical Centre Data Sheet 5581 [1965].

The ${ }^{125}$ I-insulin was obtained from The Radiochemical Centre, Amersham, Bucks, England, and had a specific activity of not less than 50 microcurics per microgram.

The anti-insulin serum and the insulin binding reagent, consisting of the antibody precipitate from the first stage of Method C of Hales and RANDLE [1963], were prepared at The Wellcome Research Laboratories. These antisera react under the conditions described with similar sensitivity to ox, human and pig insulins. The final dilution of the anti-insulin sera was $1 / 48,000$.

The sensitivity of the assay systems was 0.4 microunits insulin, and the standard deviation over the concentration range 0.4 to 10 microunits insulin was 3 to $4 \%$ of the mean.

The binding of ${ }^{125}$ I-insulin by plasma proteins was determined by the chromatographic separation used in the YALOW and BERSON [1960] immuno-assay technique.

\section{Results}

\section{a) Recognition of Interference in the Assay}

The insulin levels in the plasma of cord blood assayed by the HALES and RANDLE [1963] method are shown in table II and are in general very much higher, with the exceptions described below, than expected from previous work using the rat diaphragm method of insulin assay (BAIRD and FARQUHAR [1962]). To test the validity of these findings insulin assay by the YALow and BERSON [1960] technique was carried out in some cases but indicated negligible amounts of insulin present. This method differs essentially from that of HALES and RANDLE [1963] only in the way by which insulin bound to the added antibody is separated from the unbound 'frec' insulin.

Chromatographic separation as used in the YALOW and BERSON [1960] method showed that considerable amounts of radioactive insulin migrated on filter-paper strips with the plasma proteins of infants of insulintreated diabetic mothers, even in the absence of added anti-insulin serum. Cases 309 and 310 behaved differently, the mother of the first never having had insulin while that of the second had had none in recent years (table II).

\section{b) Localisation of the Interference}

The electrophoretic separation of plasma proteins on cellulose acetate strips in $0.04 \mathrm{M}$ barbitone buffer at $\mathrm{pH} 8.6$ following the incubation at $4^{\circ} \mathrm{C}$ at $\mathrm{pH} 7.4$ of $0.2 \mathrm{ml}$ of plasma with 250 micro-micrograms of ${ }^{125}$ I-insulin for four days indicated that where binding of ${ }^{125} \mathrm{I}$-insulin in plasma was high the radioactivity was found in the gammaglobulin and inter-betagamma zones. Where the binding was low the radioactivity was mainly in the alpha globulin zones (table III) and probably represents denatured insulin. These findings are in kecping with those of Prout et al. [1963].

On precipitation of the globulins by the addition of sodium sulphite to a final concentration of 22 per cent, 38 per cent of the radioactivity remained in the precipitate after solution and reprecipitation in the case of the infant of the diabetic mother treated with insulin, 18 per cent in the infant of the non-insulin treated diabetic mother, and 22 per cent in the infant of the non-diabetic mother. The precipitates redissolved in an 0.85 per cent solution of sodium chloride were subjected to zone electrophoresis on cellulose acetate at $\mathrm{pH}$ 8.6. The fractions representing gamma and beta globulins were the only ones present in significant amounts.

From these findings it was concluded that insulin was bound to a protein or proteins present in the gamma and inter-beta-gamma fractions of plasma and that this protein was similar or identical to the antibody produced in diabetics receiving insulin therapeutically for a period of time.

\section{c) Dilution of Interference}

An attempt was made to overcome the effects of the endogenous antibody on the assay of insulin by dilution of the plasma to give final dilutions of between 1 in 3 and 1 in 30 . Dilution beyond this was not considered practicable because of loss of sensitivity in the assay method. Where reasonable agreement was achieved between the HALES and RANDLE method and that of YALOW and Berson, dilution had reduced the effect of the endogenous antibody to negligible proportions. The effect could not be eliminated in other cases (table IV). As the interference in the immuno-assay techniques is due to a specific antibody and not to a nonspecific antagonist, the effect can at best be only minimized and not completely removed as the antibody retains a proportionate activity at any dilution.

\section{d) Plasma Insulin Response to Injected Glucose}

It was thus possible to follow the changes in insulin levels after the administration of intravenous glucose 
Table II. Cord blood plasma 'insulin' levels and ${ }^{125} \mathrm{I}-$ insulin binding (final plasma dilution 1 in 3 )

\begin{tabular}{lcl}
\hline Case No. & $\begin{array}{l}\text { Insulin } \mu \mathrm{U} / \mathrm{ml} \\
\text { (Hales and } \\
\text { Randle } \\
\text { method) }\end{array}$ & $\begin{array}{l}\text { \% radioactivity } \\
\text { bound by plasma } \\
\text { proteins (paper } \\
\text { chromatography) }\end{array}$ \\
\hline $\begin{array}{l}\text { Infants of } \\
\text { diabetics }\end{array}$ & & \\
296 & 162 & 65.2 \\
297 & $>1000$ & 53.8 \\
298 & 410 & 33.0 \\
299 & 904 & 50.8 \\
300 & $\therefore-1000$ & 46.5 \\
302 & 150 & 42.3 \\
303 & 670 & 62.8 \\
307 & $>1000$ & 59.1 \\
311 & 90 & 44.0 \\
313 & 1000 & 53.1 \\
314 & 550 & 72.5 \\
315 & 80 & - \\
309 & 24 & 19.4 \\
310 & 20 & 13.2 \\
Normal infants & & 16.4 \\
J.4400 & 21 & -1.8 \\
J.4491 & 0 & \\
J.4658 & 8 & \\
J.4688 & 61 & \\
\hline
\end{tabular}

Table III. Electrophoretic separation of insulin-binding protcins $\%$ radioactivity bound to proteins

\begin{tabular}{llll}
\hline $\begin{array}{l}\text { Protein } \\
\text { fraction }\end{array}$ & $\begin{array}{l}\text { Baby 299 } \\
\text { (mother } \\
\text { diabetic, } \\
\text { insulin- } \\
\text { treated) }\end{array}$ & $\begin{array}{l}\text { Baby 310 } \\
\text { (mother } \\
\text { diabetic, } \\
\text { not on } \\
\text { insulin) }\end{array}$ & $\begin{array}{l}\text { Normal baby } \\
\text { (mother not } \\
\text { diabetic) }\end{array}$ \\
\hline$\gamma$-globulin & 42.3 & 0 & 0 \\
Fibrinogen & 30.5 & 2.0 & 3.9 \\
$\beta$-globulin & 3.3 & 10.7 & 10.1 \\
a -globulin & 12.8 & 29.5 & 30.4 \\
a -globulin & 11.1 & 44.1 & 35.3 \\
Albumin & 0 & 13.7 & 20.3 \\
\hline
\end{tabular}

to the infants of diabetic mothers. Whilc these values do not necessarily represent the absolute amounts of insulin in the plasma, as the endogenous antibody had still some effect in most cases, it was possible to show that the infants of the diabetic mothers responded to an intravenous glucose load by sharp increments in insulin levels almost immediately (table 4) and that the insulin levels with one exception fell rapidly to values near the pre-glucose levels. In those babies, 309 and 310 , whose mothers had had no recent insulin therapy and whose plasma insulin binding capacity was correspondingly low, the rise in plasma insulin level was clear.

Table IV. Insulin levels in plasma diluted to reduce interference (newborn infants of diabetic mothers)

\begin{tabular}{|c|c|c|c|c|c|c|c|c|c|c|c|c|c|c|c|c|}
\hline \multirow{2}{*}{$\begin{array}{l}\text { Specimen } \\
\text { Baby serial } \\
\text { number }\end{array}$} & \multicolumn{16}{|c|}{ Plasma insulin in microunits $/ \mathrm{ml}$ of plasma } \\
\hline & \multicolumn{2}{|l|}{296} & \multicolumn{2}{|l|}{297} & \multicolumn{2}{|l|}{298} & \multicolumn{2}{|l|}{299} & \multicolumn{2}{|l|}{302} & \multicolumn{2}{|l|}{307} & \multicolumn{2}{|l|}{309} & \multicolumn{2}{|l|}{310} \\
\hline \multirow{2}{*}{$\begin{array}{l}\text { Final plasma } \\
\text { dilution } \\
\text { Method }^{1}\end{array}$} & \multicolumn{2}{|c|}{1 in 3} & \multicolumn{2}{|c|}{1 in 15} & \multicolumn{2}{|c|}{1 in 30} & \multicolumn{2}{|c|}{1 in 15} & \multicolumn{2}{|c|}{1 in 15} & \multicolumn{2}{|c|}{1 in 15} & \multicolumn{2}{|c|}{1 in 6} & \multicolumn{2}{|c|}{1 in 6} \\
\hline & $\mathrm{H}$ & $\mathbf{Y}$ & $\mathrm{H}$ & $\mathrm{Y}$ & $\mathrm{H}$ & $Y$ & $\mathrm{H}$ & $Y$ & $\mathbf{H}$ & $\mathrm{Y}$ & $\mathbf{H}$ & $Y$ & $\mathrm{H}$ & $\mathrm{Y}$ & $\mathrm{H}$ & $\mathrm{Y}$ \\
\hline $\begin{array}{l}\text { Time after birth } \\
\text { Maternal }\end{array}$ & - & - & - & 一 & - & - & - & - & 一 & - & 490 & 115 & 6 & 0 & 0 & 0 \\
\hline Cord 0 minutes & 162 & 一 & 1525 & 17 & 250 & - & 60 & - & 165 & 135 & 1025 & 155 & 14 & 10 & 18 & 26 \\
\hline 120 minutes & 149 & - & 590 & 13 & 70 & - & 95 & - & 80 & 85 & 440 & 110 & 10 & 0 & 11 & 0 \\
\hline Glucose & $0.5 \mathrm{~g}$ & $/ \mathrm{kg} g$ & ven qu & lickl & into $u$ & $\mathrm{mbi}$ & al ve & $\mathrm{n}$ at & $20 \mathrm{mi}$ & iutes & & & & & & \\
\hline 122 minutes & 190 & - & - & - & 200 & 一 & 260 & 一 & 390 & 185 & 1060 & 165 & 180 & 200 & 44 & 30 \\
\hline 125 minutes & 194 & $\longrightarrow$ & 775 & 19 & 140 & - & 215 & - & 275 & 145 & 735 & 140 & 102 & 156 & 33 & 40 \\
\hline 130 minutes & 191 & - & 605 & 16 & 70 & 一 & 125 & - & 185 & 120 & 625 & 150 & 44 & 48 & - & - \\
\hline 140 minutes & 204 & - & 645 & 13 & 70 & 一 & 130 & - & - & - & 630 & 120 & 24 & 19 & - & - \\
\hline 150 minutes & 220 & - & 415 & 14 & 30 & 一 & 125 & - & 100 & 90 & 450 & 100 & 10 & 12 & 11 & 0 \\
\hline 180 minutes & 220 & - & 425 & 12 & 0 & - & 105 & - & 50 & 65 & 410 & 90 & 14 & 13 & - & 一 \\
\hline 240 minutes & 202 & - & - & - & 0 & 一 & 80 & - & 65 & 65 & 270 & 80 & 24 & 19 & - & - \\
\hline
\end{tabular}

${ }^{1} \mathrm{H}=$ Hales and RANDle; $\mathrm{Y}=$ Yalow and Berson. 
As exemplified in table $\mathrm{V}$, the changes in plasma insulin levels following glucose could not be explained by changes in the binding of radioactivity by the endogenous antibody.

Table $V$. Insulin levels and the binding of radioactivity by endogenous antibody in the 4 hours after birth e.g. Baby 30 ?

\begin{tabular}{lll}
\hline $\begin{array}{l}\text { Specimen time } \\
\text { after birth }\end{array}$ & $\begin{array}{l}\text { \%oradioactivity } \\
\text { bound by plasma } \\
\text { proteins (paper } \\
\text { chromatography) }\end{array}$ & $\begin{array}{l}\text { Insulin } \mu \mathrm{U} / \mathrm{ml} \\
\text { (HANDE and }\end{array}$ \\
\hline Maternal & 39.7 & 490 \\
Cord & 35.4 & 1025 \\
120 & 36.5 & 440 \\
122 & 33.5 & 1060 \\
125 & 32.6 & 735 \\
130 & 35.3 & 625 \\
140 & 38.4 & 630 \\
150 & 36.9 & 450 \\
180 & 40.2 & 410 \\
240 & 39.3 & 270 \\
\hline
\end{tabular}

\section{Discussion}

The presence of antibodies in the plasma of insulintreated diabetics has been recognized for some time (LeRMAN [1944]; LoWell [1944]), and recently SPELLACY and GOETZ [1963] demonstrated that non-precipitating insulin-binding antibodies were found in newborn infants whose diabetic mothers had received insulin therapy. These antibodies were believed to originate in the mother.

Plasma insulin determinations by immuno-assay procedures in insulin-treated adults are made difficult by the presence of endogenous insulin antibodies (Yalow and BERson [1961]). The presence of antibody affects the assay in a way which is unique to immunoassays but the effect upon the apparent values for insulin depends upon which of the variations of the immuno-chemical methods is used. As the present work shows, the method which separates the insulin-antibody complex in the soluble form (YALOW and Berson [1960]) will give low values for insulin in the presence of endogenous antibody, while the method of HaLes and RANDLE [1963], and also that of MoRgaN and LAzAROW [1963], which separate the insulin-antibody complex in an insoluble form, gives high values for insulin in the presence of endogenous antibody. Possibly the interference by endogenous antibody could account for the high values found by immuno-assay techniques in those infants of diabetic mothers studied by Stimmler, Brazie and O'Brien [1964] as pointed out by KLINK and Estrich [1964].

YALOW and BERSON [1961] found that this problem could occasionally be overcome by making use of the great sensitivity of their immuno-assay procedure with human ${ }^{131}$ I-insulin and by diluting the plasma as much as fifty times. In the present study the apparent high values for plasma insulin could be rationalised by dilution of the plasma, though the sensitivity of the method limited the extent of dilution. The plasma of those infants whose mothers had had no or no recent insulin gave comparable results with diluted and undiluted specimens. In most cases the plasma antibodies were still capable of binding considerable amounts of ${ }^{125} \mathrm{I}$ insulin even at the greatest dilutions used, and in these cases the guinea-pig anti-insulin serum added for the assay was not able effectively to reduce the amount of radioactivity which was bound to the plasma antibody. The importance of establishing the extent to which plasma gamma globulins will bind ${ }^{125}$ I-insulin before accepting values for plasma insulin obtained by immuno-assay scems clear. This is necessary even with diluted plasma.

Preliminary extraction of plasma with acid-alcohol has been used (Grodsky and Forsham [1960]) to allow the determination of insulin in plasma from adult diabetics with circulating non-precipitating insulin antibodies. The limitations imposed on the size of the samples which could be taken from newborn infants prevented this technique from being used effectively in the present study. This same consideration also applied to the method of separation of antibody-bound insulin from unbound 'frec' insulin by gel filtration (MANipol and SpITzy [1962]). Ultra-centrifugation has also been used for this separation (YALow and BERson [1961]). An increase in the sensitivity of the method of assay together with greater dilution of plasma could offset the effects of the interference but would certainly not eliminate it in many cases.

Allowing that the effects of the endogenous antibody have not been entirely removed, the present study indicates that the infant of the diabetic mother responds to an intravenous glucose load by producing immediate and large increases in plasma insulin similar to those found previously (BAIRD and FARQUHAR [1962]). Given that the insulin levels found cannot be explained by increased binding capacity following the glucose load, and that the maternal antibody to animal insulin seems to have low affinity for human insulin (Yalow and Berson [1961]), it does appear that the infant of the diabetic mother responds to a glucose load by release of insulin. This is also the experience of Jorgensen, Deckert, Pedersen and Pedersen [1966] who, faced with the same problem of antibody inter- 
ference, found a sharp rise in insulin levels after an intravenous glucose load. In contrast to the present study they gave the glucose at a variable time after birth and chose to look for the insulin response five minutes afterward, whereas the present study suggests that the peak may already have been passed at this time. The fasting insulin levels in the two infants of non-insulin-treated diabetics in this series are low, while in the two described by JorGENSEN et al. [1966], they are high. The truth must be decided in a more extensive study, but the present finding is at least consistent with that described by BAIRD and FARQUHAR [1962]. The rapid insulin response to glucose in the babies of non-insulin-treated mothers closely resembles the pattern in those of the insulin-treated group, and is uncomplicated by insulin antibody interference in the method of assay.

\section{Summary}

The presence of antibody to exogenous insulin in the plasma of infants newly born to insulin-treated diabetic mothers makes difficult the quantitation of the plasma insulin. Failure to recognise this may cause errors both in measurement and in interpretation.

The effect of maternal antibody may be partly overcome by dilution, and in the present study this method and the investigation of babies born to two mothers who had received little or no previous insulin treatment confirms that newborn infants of diabetic mothers respond very rapidly to an intravenous load of glucose by the release of insulin. Until the problem of endogenous antibody interference with accuratc quantitation of plasma insulin by immunochemical methods is overcome, the measurement of such and of the insulin response to injected glucose may require to be confined to those babies whose mothers have not had insulin therapy.

\section{References and Notes}

1. BAIRD, J. D. and FARQUHAR, J.W.: Insulin-secreting capacity in newborn infants of normal and diabetic women. Lancet $i$ : 71 (1962).

2. Data Sheet 5581: The immunoassay of insulin using iodinated insulin-[ ${ }^{125}$ or $-\left[^{131}\right.$ and insulin binding reagent (The Radiochemical Centre, Amersham, Bucks., England 1965).

3. Grodsky, G. M. and Forsham, P.H. : An immunochemical assay of total extractable insulin in man. J.clin. Invest. 39: 1070 (1960).

4. Hales, C. N. and Randle, P.J.: Immunoassay of insulin with insulin antibody precipitate. Biochem. J. 88: 137 (1963).

5. Jørgensen, K. R.; Deckert, T.; Pedersen, L. M. and Pedersen, J.: Insulin, insulin antibody and glucose in plasma of newborn infants of diabetic women. Acta Endocr. 52: 154 (1966).

6. KLINK, D.D. and Estrich, D.: Plasma insulin levels in the newborn infants of normal and diabetic mothers. Lancet $i$ : 1393 (1964).

7. Lerman, J.: Insulin resistance: the role of immunity in its production. Amer.J.med.Sci. 207: 354 (1944).

8. Lowell, F.C.: Immunologic studies in insulin resistance. J.clin. Invest. 23: 233 (1944).

9. Manipol, V. and Spitzy, H. : Separation of I-131labelled protein-bound insulin from 'free' insulin by gel filtration. Int.J. appl. Radiat. 13: 647 (1962).

10. Morgan, C. R. and Lazarow, A.: Immunoassay of insulin: two antibody system. Plasma insulin levels of normal, subdiabetic and diabetic rats. Diabetes 12: 115 (1963).

11. Prout, T.E.; Odak, V.V.; Dendrinos, G.J. and Lockwoon, D. H.: The insulin-carrying protein of normal human serum. Diabetes 12: 144 (1963).

12. Spellacy, W.N. and Goetz, F.C.: Insulin antibodies in pregnancy. Lancet ii: 222 (1963).

13. Stimmler, L.; Brazie, J.V. and O'Brien, D.: Plasma insulin levels in the newborn infants of normal and diabetic mothers. Lancet $i$ : 137 (1964).

14. YAlOW, R.S. and Berson, S.A.: Immunoassay of endogenous plasma insulin in man. J.clin. Invest. 39: 1157 (1960).

15. Yalow, R.S. and Berson, S.A.: Immunoassay of plasma insulin in man. Diabetes 10: 339 (1961).

16. We gratefully acknowledge the support of Professor J.O. Forfar in this study, and wish also to record our thanks to Miss M.J.W.Taylor, Matron, and Miss M.Staples, Labour Ward Supervisor, of the Simpson Memorial Maternity Pavilion for the nursing help which made this study possible. We are grateful to Miss Marion Dickson, H.N.C., for skilled technical assistance. 